\title{
TEACHING AND LEARNING MECHANICS EXPLORED THROUGH THE USE OF THE 5E's EDUCATIONAL MODEL
}

PROBLEMS

OF EDUCATION

IN THE $21^{\text {st }}$ CENTURY

Vol. 80 , No. 1, 2022

179

\author{
Jean de Dieu Nkurikiyimana, Jean Uwamahoro, Kizito Ndihokubwayo \\ University of Rwanda, Rwanda \\ E-mail: nkurikiyeja3@gmail.com,mahorojpacis@gmail.com, \\ ndihokubwayokizito@gmail.com
}

\begin{abstract}
This study assesses the level of application of the 5E's educational model by Rwandan physics teachers and how the model affects the learning of basic classical mechanics in secondary school physics classrooms. For this analysis, quantitative data were collected using the classroom observation tool framed at the 5E's educational model. A sample of six secondary physics teachers was selected purposively from three boarding secondary schools of Nyamasheke district in the western province of Rwanda to participate in this study. Twenty-four classroom observations were conducted during teaching and learning mechanics concepts in the way of four observations for each teacher before being trained on 5E's educational model. This was done to help the researcher to have the real picture of the prior ability of teachers to incorporate 5E's aspects in their usual teaching practices. Similarly, a total of 24 observations were done after teachers' training. The collected data were tabulated in Microsoft Excel, and descriptive statistics were analyzed and presented. The overall mean scores on the teachers'ability to apply 5E's educational model during lesson delivery on introductory mechanics were low before training and increased due to teacher training on the use of 5E's educational model. The main findings from this study revealed that 5E's educational model is more effective in stimulating students' motivation and strong interaction and a better understanding of mechanics concepts through interactive activities, discrepant events, and computer simulations. Based on the findings of this study, some recommendations were suggested that would improve more physics students' active learning.
\end{abstract}

Keywords: active learning of mechanics, 5E's educational model, classroom observation, physics students, secondary school, Rwanda

\section{Introduction}

Nowadays, the economic development of societies worldwide is characterized by applications of science in general and physics concepts related to applications in particular. The contributions of Physics knowledge are evident in industries of engineering, transport (automobiles, trains, flights, etc.), medicine, Information and Communication Technology (REB, 2015). Therefore, achieving a technology-led economy requires effective teaching and learning of science and particularly physics. However, the world's development rate is increasing rapidly by applying science and technology that use the principles and fundamental knowledge of physics in all levels of education. Teaching and learning physics worldwide face many challenges. Among them are ineffective teaching approaches used in physics that lead the students to consider physics as an abstract subject that is difficult to learn, hence attracting fewer students than other sciences subjects like chemistry and biology (Fischer \& Horstendahl, 1997).

The challenges in teaching and learning physics include inadequate space for lab or lab facilities, insufficient funds for lab materials (Ndihokubwayo, 2017), insufficient library materials, lack of internet service; poor background of the students in mathematics, students' 
Jean de Dieu NKURIKIYIMANA, Jean UWAMAHORO, Kizito NDIHOKUBWAYO. Teaching and learning mechanics explored through the use of the $5 E^{\prime}$ 's educational mode

PROBLEMS

OF EDUCATION IN THE $21^{\text {st }}$ CENTURY Vol. 80, No. 1,2022

180

lower level of thinking capacity, poor English communication, lack of students' interest and motivation to study physics, lack of teachers' competency in their subject, lack of teachers' interest and motivation to be engaged in their professional tasks of conducting experiments and to plan a lesson, and poor method of teaching (Mekonnen, 2014). This leads to students' poor achievement in physics. This aligns with the study conducted by Uwizeyimana et al. (2018), which revealed that the difficulties in teaching and learning physics are closely linked with traditional teacher-centered teaching approaches, commonly used in Rwandan secondary physics classrooms. This method gives teachers all responsibilities for everything taking place in the classroom. At the same time, students are passive listeners of information in the whole period of learning. They are not allowed to express their perceptions, collaborate, and interact with themselves and their teachers; only they respond to teachers' questions (Nzeyimana \& Ndihokubwayo, 2019). Additionally, previous educational research indicated that what students learn is highly influenced by the pedagogical teaching methods they are taught (Chadia \& Khan, 2019).

Teaching sciences, including physics, should require the application of different teaching approaches that actively engage students, enable them to work cooperatively to construct knowledge themselves, and avoid the traditional way of memorizing facts as they are written in the documents (Duran \& Duran, 2004). Due to that, there is a need for an educational strategy for teaching and learning physics such as 5E's educational model grounded on constructivism that can help both teachers and learners to cope with $21^{\text {st }}$-century skills. Most developing countries, including Rwanda, have realized the applications of physics in all domains and decided to benefit from it by incorporating active teaching and learning. Active learning is teaching approach that involves the students in the learning process rather than being passive listeners of information from the teacher (Fayombo, 2014).

The recent research studies highlighted the effects of active learning on students' learning, such as: strengthening learning; developing students' thinking skills, communication skills, problem-solving skills; creating curiosity in students; enabling students to apply prior knowledge to a new real-life situation, promoting students' achievement; increasing students' motivation; changing students' attitudes and enabling students to learn more (Aydede \& Matyar, 2009; Chadia \& Khan, 2019; Karamustafaoglu, 2009).

\section{Inquiry-Based Educational Model}

Inquiry-based learning (IBL) is a learner-centered pedagogy that is aimed to increase students' understanding of different subjects, including science subjects. In IBL, students are encouraged to work together as a collaborative team to find out the solution of their questions by themselves throughout the understanding of their learning environment rather than receiving all instructions on what to do, how to do, and when to do from their teacher (Hussain, 2015). The teacher's role in inquiry-based learning is to facilitate learning by helping the students to discover their knowledge rather than being the source of knowledge. Through IBL, the students formulate, investigate, build new understanding based on their preceding understanding, and give meaning to their knowledge (UR-CE, 2020). IBL is one of the teaching approaches that involves active learning in the sciences, and it is a central strategy of all science curricula. For instance, it enhances various learning domains such as students' knowledge, comprehension, application, and skill development. In Indian, inquiry-based science instruction had a positive effect on students' science achievement (Ong et al., 2018). One of the strategies that can help teachers develop inquiry-based lessons is using 5E's educational learning circle approach, which consists of five phases: Engage, Explore, Explain, Elaborate, and Evaluate (Ihejiamaizu, et al., 2018) as Figure 1 illustrates. 


\section{Figure 1}

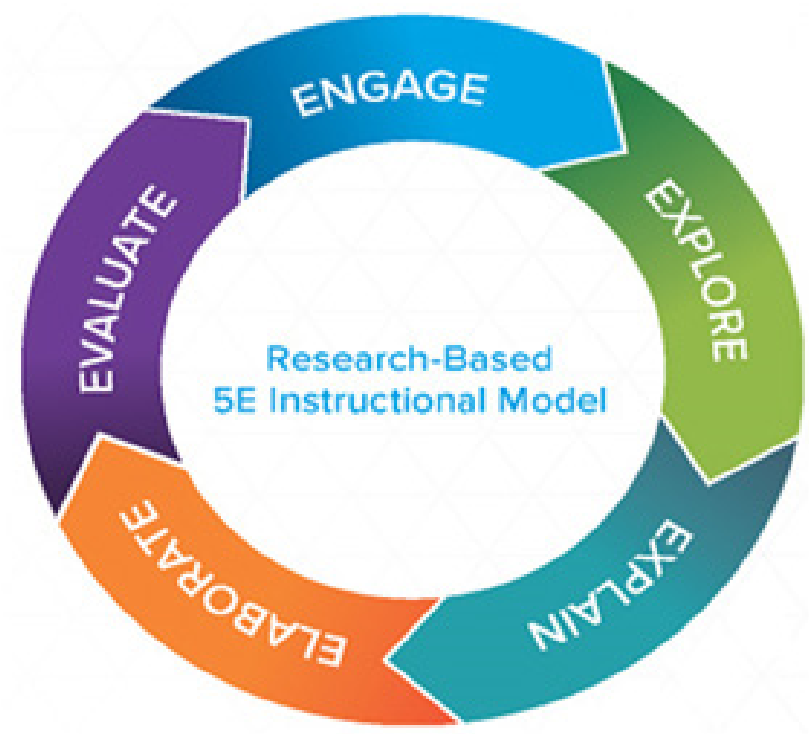

In the engagement phase, the teachers capture students' attention through exciting activities like telling a story or discrepant events related to the topic, and key questions that attract all students to be curious are formulated. It is aimed to detect students' prior knowledge, interests, and misconceptions about the topic (Alshehri, 2016; UR-CE, 2020). In the exploration phase, teachers provide enough resources and guiding questions to direct learners to do deeper research. Students brainstorm on given questions among their groups to find out the answers corresponding to their curiosity by manipulating provided learning materials. Meanwhile, teachers manage the discussion process and provide clear information on new vocabularies within the groups (Cardak et al., 2008; UR-CE, 2020). In the explanation phase, students are given enough opportunity to present and explain their findings and mention the main ideas on the chalkboard. Teachers interact with students through questions that can make the students' presentation more interesting and constructing and sounding. Meanwhile, the teachers use different techniques, including animations, simulations, and videos, to absorb any misconception that can hinder students' understanding and provide a clear explanation of scientific concepts (Aç et al., 2011; Bybee et al., 2006). In the elaboration phase, learners' understanding is trained with new challenges or daily life situations (Bybee et al., 2006; Duran \& Duran, 2004)). In the evaluation phase, the teacher assesses students' progress toward achievement of learning objectives and their teaching approach and provides feedback to the students, which will help them make reasonable decisions on the current lesson (Guzel, 2017).

\section{The 5E's Learning Model and Students'Academic Achievement}

Academic achievement can be defined as the extent to which students have attained and met either short or long-term educational goals. It can be represented by completing educational level such as secondary school diploma and at university is represented by bachelor's degree at the university level. The 5E's educational model in teaching and learning sciences, including physics, results in positive effects on students' learning and students' academic achievement. This is supported by the conducted study in Turkey by Açişli et al. (2011), which revealed that the use of the 5E's learning model is more successful and produces good results in comparison 
Jean de Dieu NKURIKIYIMANA, Jean UWAMAHORO, Kizito NDIHOKUBWAYO. Teaching and learning mechanics explored through the use of the $5 E^{\prime}$ 's educational model

PROBLEMS

OF EDUCATION

IN THE $21^{\text {st }}$ CENTURY Vol. 80, No. 1,2022

182

with traditional teaching methods. According to the study conducted by Hatice (2017), it aimed to find out the effect of electric current teaching based upon the $5 \mathrm{E}$ model on academic achievement and attitudes of students. It has revealed that the students in the experimental group who were taught based on the 5E's educational model were more successful than the students in the control group. The latter were taught based on the traditional teaching method. Based on the results from this study, it can be said that the lessons taught following the constructivist 5E's educational models using computer support and other relevant learning materials greatly affect students' achievement. However, in Turkey, including other countries, it was noticed that it is difficult to teach all lessons using 5E's model and is inappropriate for all subjects.

The 5Es educational model allows students to be more autonomous in their learning, increases their engagement and interest in science, and improves their learning outcome (Ihejiamaizus et al., 2018) and 5E's constructivist strategy is more effective than the traditional method when used in a classroom setting. This is in line with the study conducted in Ghana that indicated the significant difference between physics high-ability students in the 5E's educational group than those in the traditional group (Appiah-Twumasi et al., 2021).

\section{Purpose}

According to the study conducted by Hatice (2017), it was found that learners maximized their learning successfully. However, there are not many studies on how 5E's educational model impacts teaching and learning physics in Rwanda, yet it was found to be more effective for both teachers and students. Therefore, based on the positive effects of 5E's on both teachers and students highlighted in different research studies, the researchers wanted to evaluate the possible impact of the 5E's model during the teaching and learning process of physics in Rwandan secondary schools, which is not the case in almost all available pieces of literature. The specific objectives of this study were to assess the current teaching approaches and challenges related to the teaching and learning of physics in secondary schools and evaluate the possible impact of the 5E's model during the learning and learning process of physics in secondary physics classrooms.

\section{Research Methodology}

\section{Focus and Sample}

This is a pre/post-observation research design. Quantitative approach was employed to collect and analyze the data. This study was conducted from January to March 2021 in three selected secondary schools, namely: Groupe Scolaire Frank Adamson Kibogora (G.S.F.K); Groupe Scholaire Saint Joseph Nyamasheke (G.S. St Joseph Nyamasheke), and Institut Sainte Famille de Nyamasheke (I.S.F. Nyamasheke) located in Nyamasheke district, the Western Province in Rwanda. It involved six secondary physics teachers, among which three were ordinary level (O-level) secondary teachers, and the other three were Advanced level (A-level) secondary school teachers; all six teachers have a background of education added to their teaching content (physics major). The location of the study, the sample schools, and the teachers were selected purposively because the schools had a wide diversity of combinations with physics as a major subject, and the researcher (first author) has been teaching physics in this district and had previous information about teaching and learning facilities. For instance, four out of six teachers have all graduated from the former Kigali Institute of Education (current University of Rwanda - College of Education, UR-CE). They have been awarded a bachelor's degree in physics with education. The other two who graduated from other institutions have studied for a postgraduate diploma in education (PGDE) offered by UR-CE, qualifying them as 
Jean de Dieu NKURIKIYIMANA, Jean UWAMAHORO, Kizito NDIHOKUBWAYO. Teaching and learning mechanics explored through the use of the $5 \mathrm{E}^{\prime} \mathrm{s}$ educational model

professional teachers. Everyone has got a minimum of one training on the Competence-Based Curriculum (CBC).

\author{
PROBLEMS \\ OF EDUCATION \\ IN THE $21^{\text {st }}$ CENTURY \\ Vol. 80 , No. 1,2022 \\ 183
}

\section{Instrument and Data Collection Procedure}

To collect the data, the researchers, with permission from the district, visited the desired schools and contacted the headteachers and teachers to discuss the study's objectives. The teachers shared their school timetable with the researchers, and the researchers planned classroom observations during a lesson delivery before training on the 5E's educational model. Each teacher was observed four times using a classroom observation tool (see Appendix A) developed by VVOB and UR-CE staff to assess the current teaching approach, the challenges related to physics teaching practices before being trained on the 5Es educational model, and the level of application of the 5E's educational model in teaching (UR-CE, 2021).

The tool (template) was developed for use in the Continuous Professional Development Certificate in Educational Mentoring and Coaching for STEM Teachers (CPD-CEMCMT) (VVOB Rwanda, 2020). This tool has 11 educational aspects divided into three themes of the 5 Es model. The first two items or statements are related to the introduction of the lesson, where the teacher excites and engages students. Lesson development is investigated from item-3 to item-9, where students explore, explain, and elaborate on the learning content. Finally, the teacher concludes the lesson by letting students evaluate their learning (covered in item-10 and 11). Each item is coded or evaluated on five scales where "1" means the low occurrence of activity in the item while " 5 " is when the teacher or students fully do the activity.

After pre-observations, the researchers planned and organized teachers' training. The following activities were covered: discussions, sharing ideas, presentations about 5E's educational model, making lesson plans based on 5Es (see Appendix B), and having teaching sessions for some physics lessons based on 5Es educational model. After being familiar with and having a common understanding of 5E's models, in the same way, the researchers observed each teacher four times after training. A total of forty-eight (48) classroom observations were done so that each teacher's classroom observations before training and after training on the 5E's educational model on related mechanics lessons were conducted within three months (from January up to March 2021).

To ensure the effectiveness and reliability of the research tool, before starting the intervention, the researchers (a team of two observers) read the protocol several times for more understanding and comprehension. Then, the researchers observed a video of a teacher delivering a physics lesson for reliability calculation (as in Ndihokubwayo, et al., 2020). After watching the first video, the researchers found the 0.53 inter-observer reliability coefficients. Researchers watched a second video and found the 0.62 inter-observer's reliability. Lastly, the researchers watched the third video and found 0.72 , which is considered high-reliability coefficients. Usually, there are four cut-off points for reliability, which include excellent reliability ( 0.90 and above), high reliability $(0.70-0.90)$, moderate reliability $(0.50-0.70)$, and low reliability ( 0.50 and below) (Webb et al., 2006). Appendix B was used as a sample of a lesson plan based on 5E's educational model.

\section{Ethics}

Before collecting data, the researchers sought ethical clearance from the unity of research and innovation at UR-CE. The participants were informed and showed the purpose of the study. The research was conducted with respect to ethical values, moral expectations, and rules governing the conduct of research, especially in data collection, such as anonymity and confidentiality of the data. 
Jean de Dieu NKURIKIYIMANA, Jean UWAMAHORO, Kizito NDIHOKUBWAYO. Teaching and learning mechanics explored through the use of the $5 E^{\prime}$ s educational model

PROBLEMS

OF EDUCATION

IN THE $21^{\text {st }}$ CENTURY

Vol. 80, No. 1,2022

184
Data Analysis

To use this tool, the researcher rated on a 5-points Likert scale (from 1: being the lowest to 5: being the highest) the instruction aspect across classroom observation while the teachers delivered the lesson before and after teachers' training on 5E's educational model. Note that the highest score is 5 while the minimum score is 1 . For instance, when the item is scored " 1 " or rated under the first scale, it means the teacher was not observed doing appropriately the activity described under that item. Likewise, it scored 5 or rated under the last scale when a teacher is observed doing everything expected and required described in a certain item (among eleven items of observation tool in Appendix A). The collected data were tabulated in Microsoft Excel 2016 sheets. And a descriptive statistic was used to analyze the mean and standard deviation of the results for both observations before and after teachers' training on the use of 5E's educational model. Thus, since the data were recorded on paper during data collection, the researchers recoded them into spreadsheets after data collection. The data were recorded in a way that the number assigned among five scales of the tool used is horizontally averaged to reveal the average score along each of 11 items.

\section{Research Results}

The present study aimed to assess the current teaching approaches and challenges related to the teaching and learning of physics in secondary schools and evaluate the possible impact of using the 5Es model in teaching and learning secondary Physics classrooms. Table 1 presents the means $(\mathrm{M})$ and standard deviations $(S D)$ of teacher's ability to apply 5E's educational model before and after training. The average mean score for each item is presented. Thus, the lowest score was found on item-4 (1.96 out of 5) before training, while the highest score was found on item-3 (4.96 out of 5) after training. Generally, it was found that teachers' teaching practice was low (2.39 out of 5); however, after training on 5Es model, they have upgraded their teaching practice drastically (4.79 out of 5) (see Table 1 ). 
Jean de Dieu NKURIKIYIMANA, Jean UWAMAHORO, Kizito NDIHOKUBWAYO. Teaching and learning mechanics explored through the use of the $5 E^{\prime}$ 's educational model

Table 1

Comparison of Means (M) and Standard Deviations (SD) of Teacher's Ability to Apply 5E's PROBLEMS OF EDUCATION IN THE $21^{\text {st }}$ CENTURY Vol. 80 , No. 1,2022 Educational Model Before and After Training

\begin{tabular}{|c|c|c|c|c|c|}
\hline \multirow{2}{*}{ SN } & \multirow{2}{*}{ Educational aspects } & \multicolumn{2}{|c|}{ Pre-observation } & \multicolumn{2}{|c|}{ Post- observation } \\
\hline & & M & $S D$ & M & $S D$ \\
\hline \multicolumn{6}{|c|}{ Introduction (Excite / Engage) } \\
\hline 1 & $\begin{array}{l}\text { The teacher introduced with a real material/ story/context/ discrepant } \\
\text { event that engages and makes learners excited }\end{array}$ & 2.08 & 0.41 & 4.58 & 0.50 \\
\hline 2 & The engage/ excite activity leads to formulation of a key question & 2.04 & 0.36 & 4.71 & 0.46 \\
\hline \multicolumn{6}{|c|}{ Lesson development (Explore/Explain/Elaborate) } \\
\hline 3 & $\begin{array}{l}\text { New content is explored with a well-chosen real experiment/ video/ } \\
\text { animation/diagram(s)/3D model }\end{array}$ & 2.00 & 0.42 & 4.96 & 0.20 \\
\hline 4 & Demonstration or practical work are didactically well performed & 1.96 & 0.55 & 4.92 & 0.28 \\
\hline 5 & Teacher uses too less/ enough/ too much questioning & 2.54 & 0.51 & 4.79 & 0.41 \\
\hline 6 & Explanation is guided with good visualization & 2.54 & 0.59 & 4.83 & 0.38 \\
\hline 7 & $\begin{array}{l}\text { What can be explained by learners is explained by learners and not } \\
\text { by teachers }\end{array}$ & 2.46 & 0.51 & 4.75 & 0.53 \\
\hline 8 & Main ideas are noted on the blackboard and in a notebook & 3.00 & 0.51 & 4.83 & 0.38 \\
\hline 9 & $\begin{array}{l}\text { Understanding is trained with new challenges or daily life situations in } \\
\text { an elaborate phase }\end{array}$ & 2.75 & 0.53 & 4.88 & 0.45 \\
\hline \multicolumn{6}{|c|}{ Conclusion (Evaluate) } \\
\hline 10 & $\begin{array}{l}\text { Lesson ends with questions in order to repeat/ synthesize/ test } \\
\text { understanding of goals/ new knowledge (answer on Key question) }\end{array}$ & 2.58 & 0.65 & 4.71 & 0.55 \\
\hline \multirow[t]{2}{*}{11} & $\begin{array}{l}\text { All learners are involved: through using voting techniques, learner } \\
\text { activities during group work, assigning roles during group work, etc. }\end{array}$ & 2.38 & 0.58 & 4.71 & 0.55 \\
\hline & Overall & 2.39 & 0.51 & 4.79 & 0.43 \\
\hline
\end{tabular}

Figure 2 averages the data presented in table 1. It is a graphical representation that indicates the mean and standard deviation for all teachers about activities across all educational aspects (included in introduction, development, and conclusion) in teaching and learning on four observed lessons delivered before and after teacher training on the 5E's educational model. 
Jean de Dieu NKURIKIYIMANA, Jean UWAMAHORO, Kizito NDIHOKUBWAYO. Teaching and learning mechanics explored through the use of the $5 E^{\prime}$ s educational mode

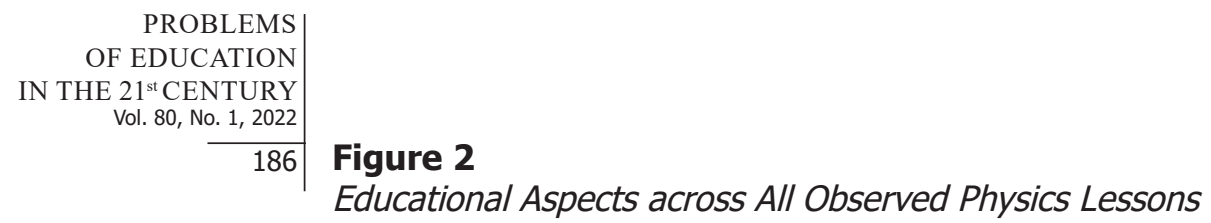

- Introduction (Excite / Engage) = Lesson development (Explore/Explain/Elaborate) $\quad$ Conclusi on (Evaluate)

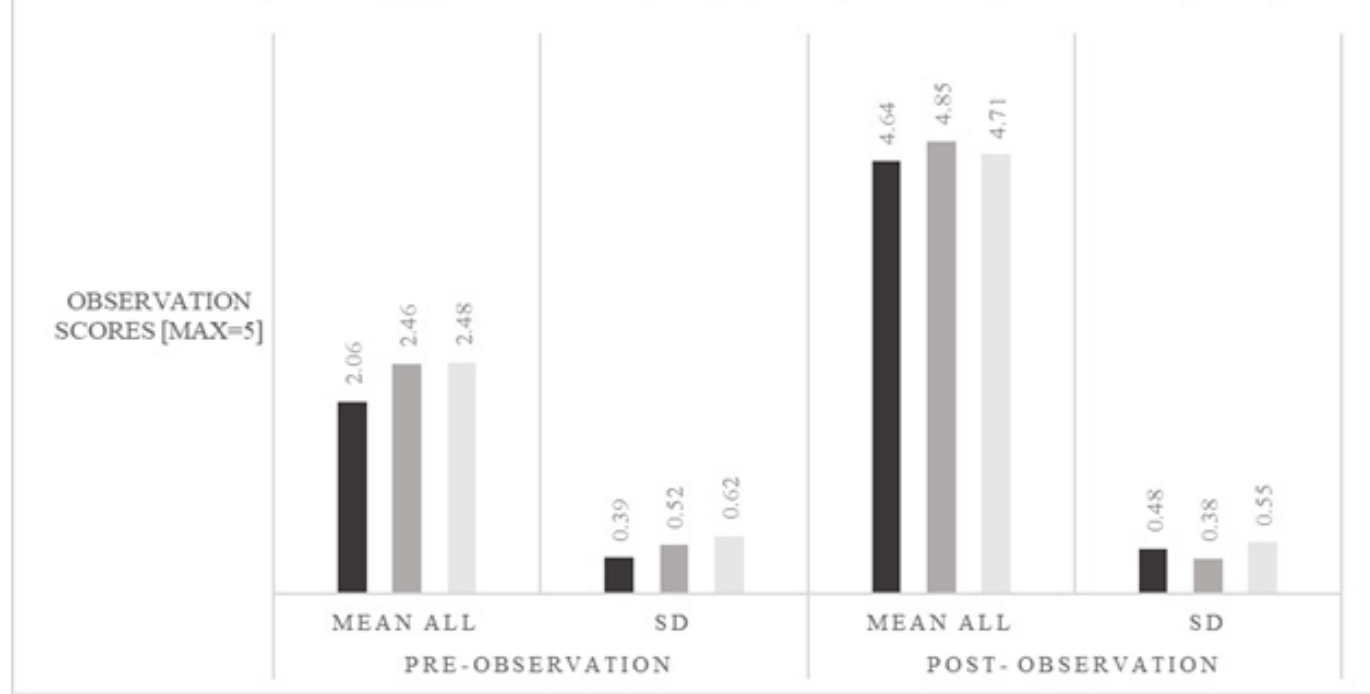

Summing up the data obtained in this study that focus on mechanics concepts, the overall mean score, $M=2.39$ out of 5 (corresponding to $47.8 \%$ ) across all 11 statements of the tool used, was very low due to the teaching approach used. While using the same tool after teachers' training on 5E's educational model, the mean scores were increased up to $M=4.79$ (95\%). This improvement was made due to the different habit changes of teachers and learners. For example, the improvement of teachers' innovation and creativity during engaging activities, the use of enough improvised resources as well as the use of ICT tools, using high order thinking questions, and ending of a lesson with an evaluation with constructive feedback, allowing the learners to express their findings with confidence, as well as their level of asking questions, and their way of using knowledge to the real-life situations.

\section{Discussion}

Before training, the lowest mean score of 1.96 (39.2\%) out of 5 was found at educational aspect 4 (Demonstration or practical work are didactically well performed). This is because most of all teachers that participated in this study did not prepare the practical materials (didactic materials) which can help in the exploration of the lesson of work, like pushing a box on a table which can give the big picture to the learners on the relationship between force, displacement and work; that can help in turn the learners to manipulate tangible surrounding materials in order to enhance their understanding on work concepts. In comparison, the highest mean score of $3.00(60 \%)$ out of 5 was found at the statement 8 (Main ideas are noted on the blackboard and in a notebook). This is because two teachers among the observed ones allowed the learners to present their findings. Their presentations marked the main ideas related to force, work, displacement, energy, and power on the blackboard and discussed them openly.

Almost all visited teachers did not engage the students during the introduction of the lesson. The teachers wrote notes on the chalkboard, and learners copied the notes in their notebooks without understanding. The researchers were expected to observe teachers introducing the lesson of work by using real examples like pushing the wall of the classroom, displacing a table 
in front of the learners, and asking learners some key questions that will help them understand the concept of work as well as its types. It would be better if the teacher used an example of fetching water by using a jerrican from girls' dormitory to their respective class and asked them some questions that would help them deduce the work formula. This teaching approach neither stimulates nor motivates the students to learn during the lesson development. It could be better if the teachers could introduce the lessons by performing some practical activities or telling a story related to the lesson that engages the students to develop their interest and a positive attitude toward the subject.

During the lesson development, the teachers explained written notes, types of work (positive work, negative work, and zero work), and learners were the guests. Throughout the lesson, the learner's contributions were not considered. This strategy does not address students' needs and interests, which positively affect students' learning and performance (Wieman, \& Perkins, 2005). Even it does not produce good results (Hussain, 2015; Madu, 2012). It was expected to find more resources that can be used for deeper exploration, sustain strong discussion among the groups, enough guiding questions for a deeper understanding of work concept and the contribution of teachers in controlling the group discussion, and explicit the new vocabulary within the groups. In addition, the researchers were expecting to observe learners' presentations on the different types of work linked to the general formula and make a product that connects the work concept to the real-life situation.

During the conclusion of the lesson, most teachers did not evaluate the learning objectives of the lesson. While evaluating the lesson's learning objectives is a key aspect that helps the teachers know each student's progress, it motivates the students to learn. It has powerful direct and indirect impacts that are very thoughtful planning and implementation (Ong et al., 2018). In general, during pre-observation, the teaching and learning environment was bored due to the teacher-centered approach. Most of the learners were not interested and were absent minded. Normally, teaching Physics should require a teaching approach that engages learners actively to work cooperatively and construct knowledge themselves instead of the way of memorization (Duran \& Duran, 2004; Ndihokubwayo et al., 2021).

After teachers' training on the 5E's educational model, the overall mean score of 4.79 (95\%) out of 5 with a standard deviation of 0.40 was obtained across all 11 statements for all six teachers. Teachers were able to prepare an appropriate lesson plan. Ndihokubwayo, Ndayambaje, et al. (2020) presented a thorough model lesson that can be adapted to teachers. During the engaging phase, most of the teachers tried their best to improve their way of creativity and innovation by preparing exciting activities like displacing a desk from one side in the class to another location, singing an interesting song called "work key for life" that grabs most students' attention and curiosity and generating key questions that pull students' involvement in the lesson. This strategy was helpful as long as other learners' talents are also developed. Most of the learners were motivated and curious to know what would be next. In the exploration phase, enough resources were provided and guiding questions to help learners explore deeply. It was an amazing phase where learners were really concentrated on finding the answers to the asked questions, and strong discussion was conducted among the groups and the way the teacher helped each group. During the explanation phase, the presentation was conducted by learners with full confidence to express their ideas with a more energetic voice to convince the rest of the class. It was really an interesting period where learners got an opportunity to explicate the concept of work by using class mopping activity; where learners said that during mopping our class from one corner to another, we applied a certain force, the displacement of water was observed, which described the work done. From this activity, they deduce the formula for work and differentiate different types of work. Such findings were also found when students were exposed to Laboratory activities, YouTube videos, and PhET simulations (Uwamahoro et al., 2021). An interesting product was made in the elaboration 
Jean de Dieu NKURIKIYIMANA, Jean UWAMAHORO, Kizito NDIHOKUBWAYO. Teaching and learning mechanics explored through the use of the $5 E^{\prime}$ 's educational mode

PROBLEMS

OF EDUCATION

IN THE $21^{\text {st }}$ CENTURY Vol. 80, No. 1,2022

188

phase, where one among the learners came up with a poem on the impact of work in real-life situations. And other groups wrote one page that indicated different situations where different types of work are applied. Reaching the evaluation phase, the teachers provided individual evaluation linked to the learning targets and provided constructive feedback to the learners based on their results obtained through evaluation.

During the conclusion, almost all teachers showed an improvement after teachers' pieces of training as indicated at educational aspects 10 and 11, which had equal mean scores of 4.71 (94.2\%) out of 5. This result showed that all teachers get the big picture of evaluation's impact on the teaching and learning process. Therefore, obtaining frequent feedback on your teaching, getting regular insight on student learning plays a central role in decision making (Clipa, 2019).

\section{Conclusions and Recommendations}

This study intended to evaluate the teaching and learning mechanics in Rwanda. This was explored through the use of the 5E's educational model. Teachers were observed and found a low level of classroom practice. They were trained in using 5E's model, and the main findings indicated that the use of 5E's educational model is more effective in improving the quality of teaching and learning, fostering and stimulating students' interest in learning, and enhancing the students' ability to understand the concepts of mechanics. Students were engaged in exciting activities, teachers allowed students to explore the learning inputs, and they were able to explain the concepts of mechanics in a fashion way. Teachers gave them opportunity to elaborate more on the learning content and therefore evaluate learning achievement. However, the study was limited in assessing learning through classroom observation. Students' achievement or conceptual understanding were not tested. The researchers recommend educational stakeholders to take into consideration this model and plan teacher training on the use of the 5E's educational model in teaching for all science teachers and distribute enough teaching and learning materials for ensuring the effective implementation of the 5E's educational model in teaching and learning physics. Moreover, the researchers recommend further studies to assess students' performance after implementing this model, cover a large number of schools and teachers about the impact of the 5E' educational model in teaching physics, and use inferential statistics so that the generalization of the findings can be made to the whole country. It is also recommended to research the impact of 5E's model in other science subjects, including chemistry and biology, to generalize the effectiveness of 5E's educational model not only in physics but in all sciences.

\section{Acknowledgment}

The researcher would like to appreciate the contribution of VVOB and UR-CE, lectures members for developing the observation tool used in this research while collecting data. The first Author thanks the African Center of Excellence for Innovative Teaching and Learning Mathematics and Science (ACEITLMS) for the full financial support provided while conducting this research.

\section{Declaration of Interest}

The authors declare no competing interest.

\section{References}

Açışlı, S., Altun, S. Y., \& Turgut, Ü. (2011). Effects of the 5E learning model on students' academic achievements in movement and force issues. Procedia Social and Behavioral Sciences, 15, 24592462. https://doi.org/10.1016/j.sbspro.2011.04.128 
Alshehri, M. A. (2016). The impact of using 5E's instructional model on achievement of mathematics and retention of learning among fifth grade students. IOSR Journal of Research \& Method in Education (IOSR-JRME), 6(2), 43-48. https://doi.org/10.9790/7388-06214348

Appiah-Twumasi, E., Nti, D., Acheampong, R., \& Eminah, C. (2021). Effect of the 5E instructional model on physics academic achievement based on gender and students' ability: A case of Berekum senior high schools in Ghana. East African Journal of Education and Social Sciences, 2(1), 1-10. https://doi.org/10.46606/eajess2021v02i01.0060

Aydede, M. N., \& Matyar, F. (2009). The effect of active learning approach in science teaching on cognitive level of student achievement. Journal of Turkish Science Education, 6(1), 115-127.

Bybee, R. W., Taylor, J. A., Gardner, A., Van, P., Powell, J. C., Westbrook, A., Landes, N., Spiegel, S., Stuhlsatz, M. M., Ellis, A., Thomas, H., Bloom, M., Moran, R., Getty, S., \& Knapp, N. (2006). The BSCS 5E instructional model: Origins and effectiveness. Colorado Springs, Co: BSCS, 5, 88-98.

Cardak, O., M. Dikmenli, M., Sartas, O. (2008). Effect of 5E instructional model in student success in primary school 6th year circulatory system topic. Asia-Pacific Forum on Science Learning \& Teaching, 9(2), 1-11. https://www.eduhk.hk/apfslt/download/v9 issue2 files/cardak.pdf

Chadia A.Aji, \& Khan, M. J. (2019). The Impact of Active Learning on Students 'Academic Performance. Open Journal of Social Sciences, 7(3), 204-211. https://doi.org/10.4236/jss.2019.73017

Clipa, O. (2019). The impact of evaluation on learning process - teachers perceptions. In Science Teaching Reconsidered (Issue August, pp. 1908-1917). https://doi.org/10.15405/epsbs.2019.08.03.235

Duran, L., \& Duran, E. (2004). The 5E instructional model: A learning cycle approach for inquiry-based science teaching. Science Education Review, 3(2), 49-58.

Fayombo, G. A. (2014). Active learning strategies and student learning outcomes among some university students in Barbados. Journal of Educational and Social Research, 2(9), 79-79. https://doi.org/10.5901/jesr.2012.v2n9p79

Fischer, H. E., \& Horstendahl, M. (1997). Motivation and learning physics. Research in Science Education, 27(3), 411-424. https://doi.org/10.1007/BF02461762

Gutulo, S. G., \& Tekello, K. O. (2015). Problems in the teaching and learning of physics in the secondary and preparatory schools, the cases of Wolaita and Dwuro zones. Global Journal of Human Social Science $(G), 15(7), 1-5$.

Guzel, H. (2017). The effect of electric current teaching based upon the 5E model on academic achievement and attitudes of students. Asia-Pacific Forum on Science Learning and Teaching, 18(2), 1-21. https://www.eduhk.hk/apfslt/download/v18_issue2_files/guzel.pdf

Hussain, S. (2015). Effect of inquiry teaching method on academic achievements of male students in subject of physics. European Academic Research, 2(12), 15461-15473.

Ihejiamaizu, C. C., Ukor, D. D., \& Neji, H. A. (2018). Utilization of 5Es' constructivist approach for enhancing the teaching of difficult concepts in biology. Global Journal of Educational Research, 17(1), 55. https://doi.org/10.4314/gjedr.v17i1.8

Karamustafaoglu, O. (2009). Active learning strategies in physics teaching. Energy Education Science and Technology Part B: Social and Educational Studies, 1(1), 27-50.

Madu, B. C. (2012). Effect of five-step learning cycle model on students' understanding of concepts related to elasticity. Journal of Education and Practice, 3(9), 173-181. https://doi.org/10.1017/CBO9781107415324.004

Mekonnen, S. (2014). Problems challenging the academic performance of physics students in higher governmental institutions in the Case of Arbaminch, Wolayita Sodo, Hawassa and Dilla Universities. Natural Science, 06(05), 362-375. https://doi.org/10.4236/ns.2014.65037

Ndihokubwayo, K. (2017). Investigating the status and barriers of science laboratory activities in Rwandan teacher training colleges towards improvisation practice. Rwandan Journal of Education, 4(1), 47-54.

Ndihokubwayo, K., Ndayambaje, I., \& Uwamahoro, J. (2020). Analysis of lesson plans from Rwandan physics teachers. International Journal of Learning, Teaching and Educational Research, 19(12), 1-29. https://doi.org/10.26803/ijlter.19.12.1

Ndihokubwayo, K., Nyirahabimana, P., \& Musengimana, T. (2021). Teaching and learning bucket model: Experimented with mechanics baseline test. European Journal of Educational Research, 10(2), 525-536. https://doi.org/10.12973/eu-jer.10.2.525 
Jean de Dieu NKURIKIYIMANA, Jean UWAMAHORO, Kizito NDIHOKUBWAYO. Teaching and learning mechanics explored through the use of the $5 E^{\prime}$ s educational mode

PROBLEMS

OF EDUCATION IN THE $21^{\text {st }}$ CENTURY Vol. 80 , No. 1,2022

190

Ndihokubwayo, K., Uwamahoro, J., \& Ndayambaje, I. (2020). Implementation of the competencebased learning in Rwandan physics classrooms: First assessment based on the reformed teaching observation protocol. EURASIA Journal of Mathematics, Science and Technology Education, 16(9), 1-8. https://doi.org/https://doi.org/10.29333/ejmste/8395

Nzeyimana, J. C., \& Ndihokubwayo, K. (2019). Teachers' role and learners' responsibility in teaching and learning science and elementary technology in Rwanda. African Journal of Educational Studies in Mathematics and Sciences, 15(2), 1-16. https://www.ajol.info/index.php/ajesms/article/ view/188762

REB. (2015). Advanced level Physics syllabus. Ministry of Education. https://reb.rw/fileadmin/ competence_based_curriculum/syllabi/Upper_Secondary/SCIENCE/Physics_CB_Advanced_ Level_Final.pdf

UR-CE. (2020). Continuous professional Development Certificate in Educational Mentoring and Coaching for STEM Teacher, students manual. Volume2: Technological Pedagogical Content Knowledge and Gender in STEM Education, Kigali.

UR-CE. (2021). Continous Professional Development Certificate in Educational Mentoring and Coaching for STEM Teachers, Student Manual, Module 2: Technological Pedagogical Content Knowledge and Gender in STEM Education (PDM1142), Fourth Edition.

Uwamahoro, J., Ndihokubwayo, K., Ralph, M., \& Ndayambaje, I. (2021). Physics students' conceptual understanding of geometric optics: Revisited analysis. Journal of Science Education and Technology, 30, 706-718. https://doi.org/10.1007/s10956-021-09913-4

Uwizeyimana, D., Yadav, L. L., Musengimana, T., \& Uwamahoro, J. (2018). The impact of teaching approaches on effective physics learning: An investigation conducted in five secondary schools in Rusizi District, Rwanda. Rwandan Journal of Education, 4(2), 4-14.

VVOB Rwanda. (2020). Professional learning communities. A toolkit for school leaders in back-toschool efforts after COVID-19 Closures, June. https://rwanda.vvob.org/download/professionallearning-communities-toolkit-school-leaders-back-school-efforts-after-covid-19

Wieman, C., \& Perkins, K. (2005). Transforming physics education. Physics Today, 58(11), 1-13. https://doi.org/https://doi.org/10.1142/9789812813787_0103

Appendix A. The observation guiding tool used to assess the teaching based on the 5Es educational model

\begin{tabular}{|c|c|c|c|c|c|c|}
\hline & Educational aspects & 1 & 2 & 3 & 4 & 5 \\
\hline \multicolumn{7}{|c|}{ Introduction (Excite / Engage): } \\
\hline 1 & $\begin{array}{l}\text { The teacher introduced with a real material/ story/context/ } \\
\text { discrepant event that engages and makes learners excited }\end{array}$ & & & & & \\
\hline 2 & $\begin{array}{l}\text { The engage/ excite activity leads to the formulation of a key } \\
\text { question }\end{array}$ & & & & & \\
\hline \multicolumn{7}{|c|}{ Lesson development (Explore/Explain/Elaborate) } \\
\hline 3 & $\begin{array}{l}\text { New content is explored with a well-chosen real experiment/ } \\
\text { video/ animation/diagram(s)/3D model }\end{array}$ & & & & & \\
\hline 4 & A demonstration or practical work are didactically well performed & & & & & \\
\hline 5 & The teacher uses too less/ enough/ too much questioning & & & & & \\
\hline 6 & The explanation is guided with good visualization & & & & & \\
\hline 7 & $\begin{array}{l}\text { What can be explained by learners is explained by learners and } \\
\text { not by teachers }\end{array}$ & & & & & \\
\hline 8 & Main ideas are noted on the blackboard and in a notebook & & & & & \\
\hline
\end{tabular}


Jean de Dieu NKURIKIYIMANA, Jean UWAMAHORO, Kizito NDIHOKUBWAYO. Teaching and learning mechanics explored through the use of the $5 E^{\prime}$ 's educational model

PROBLEMS

OF EDUCATION

IN THE $21^{\text {st }}$ CENTURY

Vol. 80 , No. 1, 2022

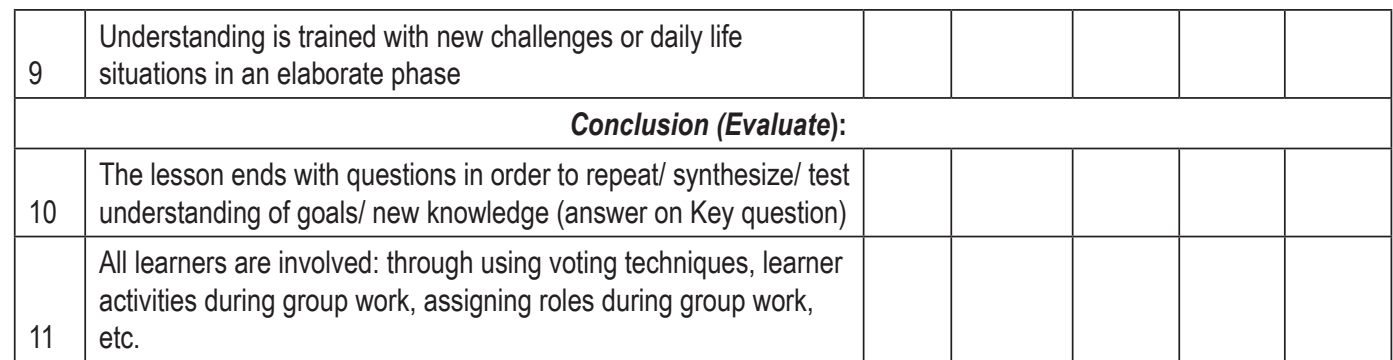

APPENDIX B. LESSON PLAN ON WORK

School name:

Teacher's name:

\begin{tabular}{|c|c|c|c|c|c|c|}
\hline Term & Date & Subject & Class & $\begin{array}{l}\text { Unit Lesson } \mathrm{N}^{\circ} \\
\mathrm{N}^{0}\end{array}$ & Duration & $\begin{array}{l}\text { Class } \\
\text { size }\end{array}$ \\
\hline 2 & $\ldots . / \ldots / 2021$ & Physics & S2 & 8 of 4 & $\begin{array}{l}40 \\
\text { minutes }\end{array}$ & 40 \\
\hline \multicolumn{4}{|c|}{$\begin{array}{l}\text { Type of Special Educational Needs to be catered for in this lesson and } \\
\text { number of learners in each category }\end{array}$} & \multicolumn{3}{|c|}{ No special education need } \\
\hline Topic area: & \multicolumn{6}{|c|}{ Mechanics } \\
\hline Subtopic- area: & \multicolumn{6}{|c|}{ Work, power, and energy } \\
\hline Unit title & \multicolumn{6}{|c|}{ Work, power, and energy } \\
\hline $\begin{array}{l}\text { Key Unit } \\
\text { Competence }\end{array}$ & \multicolumn{6}{|c|}{ By the end of this unit, the learner should be able to relate work, power, and energy } \\
\hline $\begin{array}{l}\text { Title of the } \\
\text { lesson }\end{array}$ & \multicolumn{6}{|l|}{ Work } \\
\hline $\begin{array}{l}\text { Educational } \\
\text { Objective }\end{array}$ & \multicolumn{6}{|c|}{$\begin{array}{l}\text { By the end of this unit, using simulations, Student's bool, and explanation, the students should be } \\
\text { able to: }\end{array}$} \\
\hline $\begin{array}{l}\text { Knowledge } \\
\text { and } \\
\text { understanding }\end{array}$ & \multicolumn{6}{|c|}{$\begin{array}{l}\text { Define the term work correctly } \\
\text { Recall the knowledge on work clearly. }\end{array}$} \\
\hline skills & \multicolumn{6}{|c|}{$\begin{array}{l}\text { Analyze the relationship between work and displacement clearly } \\
\text { Differentiate various types of works clearly. }\end{array}$} \\
\hline $\begin{array}{l}\text { Attitudes and } \\
\text { values }\end{array}$ & \multicolumn{6}{|c|}{$\begin{array}{l}\text { Appreciate application of work } \\
\text { Acquire an analytical mind to critically evaluate work, related issues. }\end{array}$} \\
\hline $\begin{array}{l}\text { Plan for } \\
\text { this Class } \\
\text { (location: in I } \\
\text { outside) }\end{array}$ & \multicolumn{6}{|l|}{ Inside } \\
\hline $\begin{array}{l}\text { Learning } \\
\text { Materials } \\
\text { (for all } \\
\text { learners) }\end{array}$ & \multicolumn{6}{|c|}{$\begin{array}{l}\text { Books, box, table, manila paper, marker, masses, inclined plane and other materials around the } \\
\text { classroom }\end{array}$} \\
\hline References & \multicolumn{6}{|c|}{$\begin{array}{l}\text { Physics learner's book for Rwanda secondary school senior two, page } 163 \text { FOUNTAIN } \\
\text { PUBLISHERS, www.fountainpublishers.co.ug, Kigali, Rwanda (2017) } \\
\text { https://phet.simulation, https://www.ophysics.com/fl.html }\end{array}$} \\
\hline
\end{tabular}


Jean de Dieu NKURIKIYIMANA, Jean UWAMAHORO, Kizito NDIHOKUBWAYO. Teaching and learning mechanics explored through the use of the $5 E^{\prime}$ s educational mode

PROBLEMS

OF EDUCATION

IN THE $21^{\text {st }}$ CENTURY

Vol. 80 , No. 1, 2022
192

\begin{tabular}{|c|c|c|c|}
\hline \multirow{3}{*}{$\begin{array}{l}\text { Timing for } \\
\text { each step }\end{array}$} & \multicolumn{2}{|l|}{ Description of teaching/learning activities } & \multirow{3}{*}{$\begin{array}{l}\text { Generic } \\
\text { competences } \\
\text { and Cross- } \\
\text { cutting issues to } \\
\text { be addressed } \\
\text { + a short } \\
\text { explanation } \\
\text { Teacher's } \\
\text { activities }\end{array}$} \\
\hline & \multicolumn{2}{|c|}{$\begin{array}{l}\text { Different activities will be used such as questions and answers, group } \\
\text { discussion, learners' explanation observation of some diagrams, pictures, and } \\
\text { giving examples and real-life applications. }\end{array}$} & \\
\hline & Teacher's activities & $\begin{array}{l}\text { Learner's } \\
\text { activities }\end{array}$ & \\
\hline $\begin{array}{l}\text { Introduction } \\
5 \text { minutes }\end{array}$ & $\begin{array}{l}\text { Engage / Excite phase: } \\
\text { The teacher Pulls or pushes a box of chalk on the table } \\
\text { and asks some questions to the students } \\
\text { What will happen when I push or } \\
\text { pull a box? } \\
\text { What will happen if you push a box with a small force? } \\
\text { What will happen if you push a box with a large force? } \\
\text { The teacher writes the key questions of the lesson } \\
\text { What is work? } \\
\text { What are the necessary conditions for the work to be } \\
\text { done? } \\
\text { What is the mathematical formula of work? } \\
\text { Differentiate three forms of work. }\end{array}$ & $\begin{array}{l}\text { The learners } \\
\text { will observe and } \\
\text { describe the } \\
\text { observations } \\
\text { from the } \\
\text { teacher's activity } \\
\text { and answer the } \\
\text { asked questions. } \\
\text { The box will } \\
\text { move. } \\
\text { When you push } \\
\text { a box with a } \\
\text { small force, the } \\
\text { box will not move } \\
\text { or move slowly } \\
\text { When you push } \\
\text { a box with a } \\
\text { large force, the } \\
\text { box will move. }\end{array}$ & $\begin{array}{l}\text { GC: } \\
\text { Communication } \\
\text { skills } \\
\text { will be developed } \\
\text { through answering } \\
\text { questions } \\
\text { CC: } \\
\text { Inclusive } \\
\text { Education will } \\
\text { be catered for } \\
\text { throughout the } \\
\text { lesson } \\
\text { Gender } \\
\text { education is } \\
\text { emphasized } \\
\text { through } \\
\text { encouraging } \\
\text { all learners' } \\
\text { regardless sex } \\
\text { to participate in } \\
\text { the learning and } \\
\text { teaching process }\end{array}$ \\
\hline
\end{tabular}




\begin{tabular}{|c|c|c|}
\hline $\begin{array}{l}\text { The } \\
\text { Elaborate phase: } \\
\text { The teacher elaborates the lesson by telling a scenario } \\
\text { related to the different people doing work. } \\
\text { The first person was pushing the wall of the building, } \\
\text { the Second was pushing a box of chalks on the smooth } \\
\text { surface of the table, and the third person was pulling a } \\
\text { cow backward while the cow was still moving forward. } \\
\text { Discuss the forms of work done by each person. } \\
\text { The teacher tells the students to write their answer on their } \\
\text { notebooks so that he/she can mark their answers. } \\
\text { provides feedback. And answer some questions raised by } \\
\text { the students } \\
\text { The teacher marks the work done by the students and } \\
\text { Evaluate: } \\
\text { The teacher summarizes the lesson by providing the } \\
\text { definition of work and different forms of energy and } \\
\text { mathematical formula of work. } \\
\text { on learnin writes an individual evaluation on chalk based } \\
\text { abjectives. }\end{array}$ & $\begin{array}{l}\text { Students listen to } \\
\text { the teacher try to } \\
\text { make a correct } \\
\text { prediction. They } \\
\text { describe and } \\
\text { discuss the foam } \\
\text { of work done by } \\
\text { each person. } \\
\text { The first person } \\
\text { was doing Zero } \\
\text { work because } \\
\text { the wall was not } \\
\text { moving. } \\
\text { The second } \\
\text { person was } \\
\text { doing positive } \\
\text { work because } \\
\text { the box was } \\
\text { moving in the } \\
\text { direction of } \\
\text { applied force. } \\
\text { The third person } \\
\text { was doing } \\
\text { negative work } \\
\text { because the } \\
\text { cow was moving } \\
\text { in the opposite } \\
\text { direction of the } \\
\text { applied force. } \\
\\
\text { Listen to the } \\
\text { teacher and } \\
\text { harmonize their } \\
\text { note. } \\
\text { Apply their } \\
\text { understanding, } \\
\text { answer the } \\
\text { questions } \\
\text { Do the } \\
\text { evaluation and } \\
\text { submit the } \\
\text { answer to the } \\
\text { teacher to be } \\
\text { marked }\end{array}$ & $\begin{array}{l}\text { GC: } \\
\text { Critical thinking } \\
\text { skills will be } \\
\text { developed while } \\
\text { students explore } \\
\text { the phenomena } \\
\text { and reflect } \\
\text { on teacher's } \\
\text { questions } \\
\text { Cooperation will } \\
\text { be developed } \\
\text { through working } \\
\text { together } \\
\text { performing } \\
\text { experiment } \\
\text { CC } \\
\text { Financial } \\
\text { Education } \\
\text { Will be discussed } \\
\text { to show that } \\
\text { the income is } \\
\text { proportional to the } \\
\text { work done. } \\
\\
\text { GC: } \\
\text { Interpersonal } \\
\text { relations and } \\
\text { life skills will be } \\
\text { developed through } \\
\text { challenging each } \\
\text { other; therefore, } \\
\text { this will promote } \\
\text { the development } \\
\text { of the higher-order } \\
\text { thinking skills } \\
\text { Lifelong learning } \\
\text { will be developed } \\
\text { via contextualizing } \\
\text { the learned } \\
\text { concept } \\
\text { a }\end{array}$ \\
\hline
\end{tabular}


Jean de Dieu NKURIKIYIMANA, Jean UWAMAHORO, Kizito NDIHOKUBWAYO. Teaching and learning mechanics explored through the use of the $5 E^{\prime}$ s educational mode

PROBLEMS

OF EDUCATION

IN THE $21^{\text {st }}$ CENTURY

Vol. 80 , No. 1,2022

Received: October 14, 2021
Accepted: January 29, 2022

Cite as: Nkurikiyimana, J. D., Uwamahoro, J., \& Ndihokubwayo, K. (2022). Teaching and learning mechanics explored through the use of the 2 5E's educational model. Problems of Education in the $21^{\text {st }}$ Century, 80(1), 179-194. https://doi.org/10.33225/pec/22.80.179

Jean de Dieu Nkurikiyimana

(Corresponding author)
Bachelor of Education (Hons) Physics (Secondary), Master student at African Center of Excellence for Innovative Teaching and Learning Mathematics and Science (ACEITLMS), University of Rwanda College of Education (URCE), Kayonza, P.O Box 55 Rwamagana, Rwanda.

E-mail: nkurikiyeja3@gmail.com

ORCID: https://orcid.org/0000-0002-4020-031X

Associate Professor of Physics at University of Rwanda College of Education (URCE), Kayonza, P.O Box 55 Rwamagana,, Rwanda.

E-mail: mahorojpacis@gmail.com

ORCID: https://orcid.org/0000-0002-1730-6685

Kizito Ndihokubwayo
$\mathrm{PhD}$, Researcher, African Center of Excellence for Innovative Teaching and Learning Mathematics and Science (ACEITLMS), University of Rwanda College of Education (URCE), Kayonza, P.O Box 55 Rwamagana, Rwanda. E-mail: ndihokubwayokizito@gmail.com ORCID: https://orcid.org/0000-0002-2566-8045 